
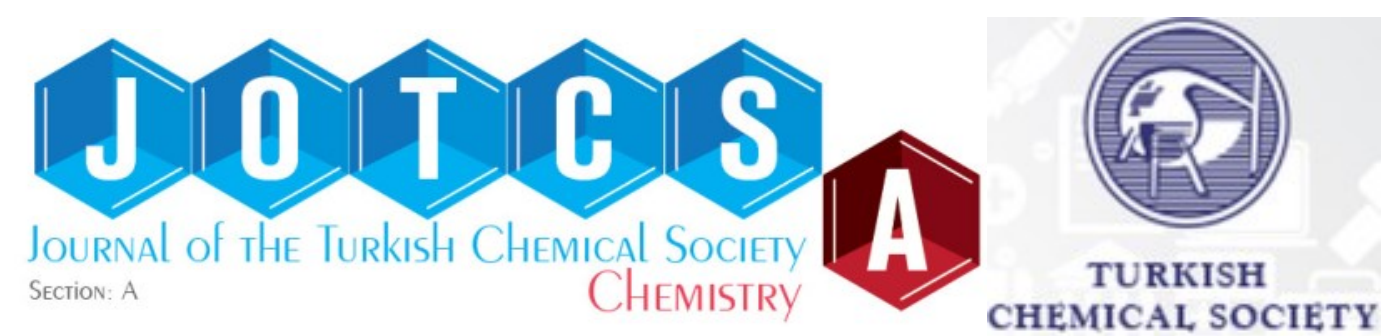

\title{
Synthesis, Characterization, and Carbonic Anhydrase Inhibitory Properties of Silver(I) Complexes of Benzimidazole Derivatives
}

\author{
Mert Olgun Karataş ${ }^{*} \otimes$, Adem Ergün ${ }^{2 *} \Delta$ \\ ${ }^{1}$ Inonu University, Faculty of Science, Department of Chemistry, 44280, Malatya, Turkey \\ ${ }^{2}$ Balikesir University, Faculty of Science, Department of Chemistry, 10440, Balikesir, Turkey
}

Abstract: The antimicrobial properties of silver compounds and biological properties of benzimidazole derivatives have been well known for many years. In the present study, in terms of their biological potential, six novel silver(I)-N-alkylbenzimidazole derivatives were synthesized in order to examine their carbonic anhydrase (CA) inhibitory properties. All complexes were characterized by the combination of $1 \mathrm{H}$ NMR, 13C NMR, mass, FT-IR spectroscopic methods and elemental analyses. The inhibitory properties of all complexes were tested on the esterase activity of human CA I and II (hCA I and hCA II). Acetazolamide was used as a standard. All complexes inhibited the hCA I and hCA II activity in the range of 27.37-29.58 $\mu \mathrm{M}$ and 20.93-27.25 $\mu \mathrm{M}$, respectively.

Keywords: Benzimidazole, silver, carbonic anhydrase, inhibition.

Submitted: March 29, 2019. Accepted: May 20, 2019.

Cite this: Karataş M, Ergün A. Synthesis, Characterization, and Carbonic Anhydrase Inhibitory Properties of Silver(I) Complexes of Benzimidazole Derivatives. JOTCSA. 2019;6(2):253-60.

DOI: https://dx.doi.org/10.18596/jotcsa.546960.

*Corresponding Authors. E-mails: mert.karatas@inonu.edu.tr , ademergun@balikesir.edu.tr

\section{INTRODUCTION}

The antimicrobial properties of silver have been known for more than two thousand years. The historical use of silver in the treatment of burns and ulcer is well documented by Klasen (1). However, at the beginning of modern coordination chemistry era, scientists mainly focused on the synthesis and catalytic activity of silver compounds. The use of silver in modern medicine began with the use of $0.5 \%$ solution of silver nitrate in the wound treatment by Moyer in 1965 (2). Three years later, Fox discovered silver sulfadiazine as a cream in the treatment of burns and wounds (3). It is known that silver does not have a toxic effect to human body at low concentrations (4). Additionally, some recent studies showed that silver has a more favorable toxicological profile compared with gold and platinum, which are other biologically relevant metals $(4,5)$. The relative safety and strong antimicrobial activity of silver compounds led many research groups to synthesize different complexes of silver and investigate their biological activity. In recent years, in addition to their antimicrobial properties, anticancer activity of silver complexes was also reported $(6,7)$.

Organometallic complexes of silver(I) also attracted much attention in recent years. The most used ligands for the synthesis of organometallic silver complexes are $N$ heterocycles (8), N-heterocyclic carbenes (NHC) (9), and phosphines (10). Benzimidazole, which is an $N$-heterocyclic compound plays highly important role in organometallic and medicinal chemistry with biological properties such as anti-helmintic, anti-ulcer, anticancer, and antimicrobial (1113). On the other hand, many transition metal 
complexes were reported in which benzimidazole acts as $N$-donor ligand (14-16). In addition, 1,3-disubstituted benzimidazolium salts are commonly used as NHC precursors in coordination chemistry (1721).

Enzyme inhibition is a highly important issue in medicinal chemistry. In addition to the important role of enzyme inhibition in anticancer mechanisms of action, inhibitors of some enzymes are used in drug design. For example, sulfonamides are carbonic anhydrase (CA, EC 4.2.1.1) inhibitors and used as anti-glaucoma drugs (22). CAs are metalloenzymes that play a critical role in physiological $\mathrm{pH}$ control by the catalyzing the reversible hydration of $\mathrm{CO}_{2}$ to bicarbonate and a proton (23). Today, seven generically distinct CA families: $a-, \beta-, \gamma_{-}^{-}, \delta-, \zeta-, \eta-$, and $\theta$-CAs, and sixteen human isoforms of a-CAs (hCAs) are known (24). Abnormal levels of CAs are associated with epilepsy (25), obesity (26), and cancer (27), in addition to glaucoma. Therefore, development of strong inhibitors without side effects is an important target for the treatment of the mentioned diseases.

Based on the information above, in this study, we synthesized six novel silver(I) complexes of $\mathrm{N}$-alkylbenzimidazoles (1-6) in order to investigate their CA inhibitory properties. The structures of these complexes were established by the combination of ${ }^{1} \mathrm{H} N M R,{ }^{13} \mathrm{C}$ NMR, IR, mass spectrometry methods and elemental analyses. Inhibitory properties of all complexes were determined by the esterase activity of hCA I and II.

\section{MATERIALS AND METHODS}

5-Nitrobenzimidazole, methyl iodide, allyl bromide, pentyl bromide, decyl chloride, $N, N$ dimethyl- $N$-(3-chloropropyl)amine, silver nitrate and the solvents were purchased from Aldrich Chemical Co and used as received. Synthesis of silver complexes was carried out under ambient conditions. The $\mathrm{C}, \mathrm{H}$, and $\mathrm{N}$ elemental analysis were determined by LECO CHNS-932 elemental analyzer. Melting points were determined in open capillary tubes by Electrothermal-9200 melting point apparatus and are not corrected. FT-IR spectra in the range of $4000-550 \mathrm{~cm}^{-1}$ were recorded in a Perkin Elmer Spectrum 100 Spectrometer by using ATR Sampling Accessory. LC-MS spectra were recorded in an Agilent 1100 LC/MSD SL mass spectrometer equipped with an electrospray ion source. ${ }^{1} \mathrm{H}$ and ${ }^{13} \mathrm{C} N M R$ spectra were recorded by using Bruker Ascend $^{\mathrm{TM}} 400$ Avance III HD operating at 400 $\mathrm{MHz}\left({ }^{1} \mathrm{H}\right), 100 \mathrm{MHz}\left({ }^{13} \mathrm{C}\right)$ and $\mathrm{DMSO}^{-\mathrm{d}_{6}}$ was used as the solvent. Chemical shifts were given in $\mathrm{ppm}$ relative to tetramethylsilane
(TMS). NMR multiplicities were abbreviated as $\mathrm{s}=$ singlet, $\mathrm{d}=$ doublet, $\mathrm{t}=$ triplet, quin $=$ quintet, $\mathrm{m}=$ multiplet, $\mathrm{dd}=$ doublet of doublets, $\mathrm{ddt}=$ doublet of doublet of triplets.

\section{Synthesis and characterization of silver(I) complexes (1-6)}

$N$-alkylbenzimidazole derivatives were synthesized by the previously reported procedure (28). $2 \mathrm{mmol}$ of $\mathrm{N}$ alkylbenzimidazole derivative was added into the suspension of $170 \mathrm{mg}$ ( $1 \mathrm{mmol}$ ) of $\mathrm{AgNO}_{3}$ in $20 \mathrm{~mL}$ of ethanol. The mixture was stirred at $50{ }^{\circ} \mathrm{C}$ for 3 hours and then allowed to cool to the ambient temperature. The precipitated crude product was collected by filtration, washed with diethyl ether $(3 \times 10 \mathrm{~mL})$, and dried under reduced pressure.

\section{Bis(N-methylbenzimidazole)silver(I)}

nitrate (1): White solid, yield: 94\% (410 $\mathrm{mg})$, mp:203-204 ${ }^{\circ} \mathrm{C}$. FT-IR spectrum $\left(\mathrm{cm}^{-1}\right)$ : $3119,1610,1515,1459 .{ }^{1} \mathrm{H}$ NMR spectrum: $\delta$ $8.62(\mathrm{~m}, 2 \mathrm{H}, \mathrm{NCHN}), 7.86-7.84$ (m, 2H, ArH), 7.76-7.74 (m, 2H, ArH), 7.41(m, 4H, ArH), $3.98\left(\mathrm{~s}, 6 \mathrm{H}, \mathrm{NCH}_{3}\right) .{ }^{13} \mathrm{C}$ NMR spectrum: $\delta$ $146.6(\mathrm{NCHN}), 141.6,133.9,124.2,123.6$, 119.4, 111.7, $31.9\left(\mathrm{NCH}_{3}\right)$. LC-MS Calculated for $\left[\mathrm{Ag}\left(\mathrm{C}_{8} \mathrm{H}_{8} \mathrm{~N}_{2}\right)\right]^{+}, \mathrm{m} / \mathrm{z}$ : 371.0; Found, 371.0. Elemental analysis, Calculated for $\mathrm{C}_{16} \mathrm{H}_{16} \mathrm{AgN}_{5} \mathrm{O}_{3} ; \mathrm{C}, 44.26, \mathrm{H}, 3.71, \mathrm{~N}, 16.13$; Found; C, 44.20, H, 3.63, N, 16.04.

\section{Bis(N-methyl-5-}

nitrobenzimidazole)silver(I) nitrate (2): White solid, yield: $90 \%$ (470 mg), mp:281$283{ }^{\circ} \mathrm{C}$. FT-IR spectrum $\left(\mathrm{cm}^{-1}\right): 3105,1623$, 1599, 1529, 1513, 1475, 1447. ${ }^{1} \mathrm{H}$ NMR spectrum: $\delta 8.79(\mathrm{~d}, 2 \mathrm{H}, J=2.2 \mathrm{~Hz}$, ArH), $8.77(\mathrm{~s}, 2 \mathrm{H}, \mathrm{NCHN}), 8.27\left(\mathrm{dd}, 2 \mathrm{H}, J_{1}=8.9 \mathrm{~Hz}\right.$, $\left.J_{2}=2.2 \mathrm{~Hz}, \mathrm{ArH}\right), 7.92(\mathrm{~d}, 2 \mathrm{H}, \mathrm{J}=8.9 \mathrm{~Hz}$, ArH), 4.00 (s, 6H, $\left.\mathrm{NCH}_{3}\right) .{ }^{13} \mathrm{C}$ NMR spectrum: $\delta 150.2(\mathrm{NCHN}), 143.7,141.7,138.6,119.1$, $116.1,112.2,32.2\left(\mathrm{NCH}_{3}\right)$. LC-MS Calculated for $\left[\mathrm{Ag}\left(\mathrm{C}_{8} \mathrm{H}_{7} \mathrm{~N}_{3} \mathrm{O}_{2}\right)_{2}\right]^{+}, \mathrm{m} / \mathrm{z}$ : 463.0; Found, 463.0. Elemental analysis, Calculated for $\mathrm{C}_{16} \mathrm{H}_{14} \mathrm{AgN}_{7} \mathrm{O}_{7} ; \mathrm{C}, 36.66, \mathrm{H}, 2.69, \mathrm{~N}, 18.70$; Found; C, 36.58, H, 2.62, N, 18.61 .

\section{Bis(N-allylbenzimidazole)silver(I)}

nitrate (3): White solid, yield: $64 \%$ (310 $\mathrm{mg}), \mathrm{mp}: 128-130{ }^{\circ} \mathrm{C}$. FT-IR spectrum $\left(\mathrm{cm}^{-1}\right)$ : 3099, 1507, 1464, 1434. ${ }^{1} \mathrm{H}$ NMR spectrum: $\delta$ 8.67 ( $\mathrm{s}, 2 \mathrm{H}, \mathrm{NCHN}), 7.91-7.88(\mathrm{~m}, 2 \mathrm{H}, \mathrm{ArH})$, 7.73-7.70 (m, 2H, ArH), $7.40(\mathrm{~m}, 4 \mathrm{H}, \operatorname{ArH})$, 6.10 (ddt, $2 \mathrm{H}, J_{1}=5.5 \mathrm{~Hz}, J_{2}=10.3 \mathrm{~Hz}, J_{3}=$ $17.3 \mathrm{~Hz}, \mathrm{NCH}_{2} \mathrm{CH}=\mathrm{CH}_{2}$ ), 5.29 (dd, $2 \mathrm{H}, J_{1}=$ $10.3 \mathrm{~Hz}, J_{2}=1.3 \mathrm{~Hz}, \mathrm{CH}=\mathrm{CH}_{2}$-cis), 5.20 (dd, $2 \mathrm{H}, J_{1}=17.2 \mathrm{~Hz}, J_{2}=1.3 \mathrm{~Hz}, \mathrm{CH}=\mathrm{CH}_{2}$-trans), $5.08\left(\mathrm{~d}, 4 \mathrm{H}, J=5.6 \mathrm{~Hz}, \mathrm{NCH}_{2} \mathrm{CH}=\mathrm{CH}_{2}\right) .{ }^{13} \mathrm{C}$ NMR spectrum: $\delta 146.1$ (NCHN), 141.9, 133.4, 133.2, 124.2, 123.6, 119.7, 118.7, 112.0, $47.6\left(\mathrm{NCH}_{2}\right)$. LC-MS Calculated for $\left[\mathrm{Ag}\left(\mathrm{C}_{10} \mathrm{H}_{10} \mathrm{~N}_{2}\right)_{2}\right]^{+}, \mathrm{m} / \mathrm{z}$ : 425.1; Found, 425.1. 
Elemental analysis, Calculated for $\mathrm{C}_{20} \mathrm{H}_{20} \mathrm{AgN}_{5} \mathrm{O}_{3} ; \mathrm{C}, 49.40, \mathrm{H}, 4.15, \mathrm{~N}, 14.40$; Found; C, 49.33, H, 4.10, N, 14.31.

\section{Bis(N-pentylbenzimidazole)silver(I)}

nitrate (4): White solid, yield: 94\% (510 $\mathrm{mg})$, mp: $73-74{ }^{\circ} \mathrm{C}$. FT-IR spectrum $\left(\mathrm{cm}^{-1}\right)$ : 3102, 2982, 2882, 2859, 1617, 1512, 1463. ${ }^{1} \mathrm{H}$ NMR spectrum: $\delta 8.67(\mathrm{~s}, 2 \mathrm{H}, \mathrm{NCHN})$, 7.89-7.86 (m, 2H, ArH), 7.80-7.77 (m, 2H, ArH), $7.40(\mathrm{~m}, 4 \mathrm{H}, \operatorname{ArH}), 4.39(\mathrm{t}, 4 \mathrm{H}, \mathrm{J}=7.0$ $\mathrm{Hz}, \mathrm{NCH}_{2}$ ), 1.85 (quin, $4 \mathrm{H}, \mathrm{J}=7.3 \mathrm{~Hz}$, $\left.\mathrm{NCH}_{2} \mathrm{CH}_{2}\right)$, 1.36-1.20 (m, 8H, $\left.\mathrm{CH}_{2} \mathrm{CH}_{2} \mathrm{CH}_{3}\right)$, $0.84\left(\mathrm{t}, 6 \mathrm{H}, \mathrm{J}=7.2 \mathrm{~Hz}, \mathrm{CH}_{2} \mathrm{CH}_{3}\right) .{ }^{13} \mathrm{C} \mathrm{NMR}$ spectrum: $\delta 146.0(\mathrm{NCHN}), 141.8,133.2$, 124.2, 123.5, 119.6, 111.8, $45.2\left(\mathrm{NCH}_{2}\right), 29.4$ $\left(\mathrm{NCH}_{2} \mathrm{CH}_{2}\right), \quad 28.6 \quad\left(\mathrm{CH}_{2} \mathrm{CH}_{2} \mathrm{CH}_{3}\right), \quad 22.1$ $\left(\mathrm{CH}_{2} \mathrm{CH}_{3}\right), 14.3\left(\mathrm{CH}_{2} \mathrm{CH}_{3}\right)$. LC-MS Calculated for $\left[\mathrm{Ag}\left(\mathrm{C}_{12} \mathrm{H}_{16} \mathrm{~N}_{2}\right)_{2}\right]^{+}$, m/z: 483.2; Found, 483.2. Elemental analysis, Calculated for $\mathrm{C}_{24} \mathrm{H}_{32} \mathrm{AgN}_{5} \mathrm{O}_{3} ; \mathrm{C}, 52.76, \mathrm{H}, 5.90, \mathrm{~N}, 12.82$; Found; C, 52.70, H, 5.84, N, 12.71 .

\section{$\operatorname{Bis}(\boldsymbol{N}-(\mathbf{3}-(\boldsymbol{N}, \mathbf{N}-$}

dimethylamino)propyl)benzimidazole)sil $\operatorname{ver(I)}$ nitrate (5): Beige solid, yields: $66 \%$ (380 mg), mp:87-88 ${ }^{\circ} \mathrm{C}$. FT-IR spectrum (cm ${ }^{-}$ $\left.{ }^{1}\right): \quad 3038,1614,1519,1460 .{ }^{1} \mathrm{H} \quad \mathrm{NMR}$ spectrum: $\delta 8.63(\mathrm{~s}, 2 \mathrm{H}, \mathrm{NCHN}), 7.87(\mathrm{~d}, 2 \mathrm{H}$, $\mathrm{J}=7.8 \mathrm{~Hz}, \operatorname{ArH}), 7.81(\mathrm{~d}, 2 \mathrm{H}, \mathrm{J}=7.8 \mathrm{~Hz}$, ArH), 7.42 (quin, $4 \mathrm{H}, J=8.6 \mathrm{~Hz}$, ArH), 4.45 $\left(\mathrm{t}, 4 \mathrm{H}, J=7.1 \mathrm{~Hz}, \mathrm{NCH}_{2} \mathrm{CH}_{2}\right), 3.15(\mathrm{~m}, 4 \mathrm{H}$, $\mathrm{CH}_{2} \mathrm{CH}_{2} \mathrm{~N}$ ), $2.79\left(\mathrm{~s}, 12 \mathrm{H}, \mathrm{N}\left(\mathrm{CH}_{3}\right)_{2}\right), 2.24$ (quin, $\left.4 \mathrm{H}, J=\mathrm{CH}_{2} \mathrm{CH}_{2} \mathrm{CH}_{2}\right)$. ${ }^{13} \mathrm{C}$ NMR spectrum: $\delta$ $145.8(\mathrm{NCHN}), 141.9,133.0,124.4,123.7$,

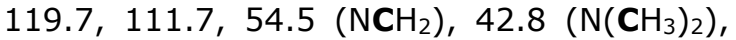
$42.5\left(\mathrm{CH}_{2} \mathrm{~N}\right), \quad 24.9 \quad\left(\mathrm{CH}_{2} \mathrm{CH}_{2} \mathrm{CH}_{2}\right)$. LC-MS Calculated for $\left[\mathrm{Ag}\left(\mathrm{C}_{12} \mathrm{H}_{17} \mathrm{~N}_{3}\right)_{2}\right]^{+}, \mathrm{m} / \mathrm{z}$ : 513.2; Found, 513.3. Elemental analysis, Calculated for $\mathrm{C}_{24} \mathrm{H}_{34} \mathrm{AgN}_{7} \mathrm{O}_{3} ; \mathrm{C}, 50.01, \mathrm{H}, 5.95, \mathrm{~N}, 17.01$; Found; C, 49.90, H, 5.82, N, 16.88 .

\section{Bis(N-decylbenzimidazole)silver(I)}

nitrate (6): White solid, yield: $82 \%$ (560 $\mathrm{mg}), \mathrm{mp}$ : 84-85 ${ }^{\circ} \mathrm{C}$. FT-IR spectrum $\left(\mathrm{cm}^{-1}\right)$ : 3100, 2985, 2915, 2851, 1619, 1511, 1464. ${ }^{1} \mathrm{H}$ NMR spectrum: $\delta 8.66(\mathrm{~s}, 2 \mathrm{H}, \mathrm{NCHN})$, 7.88-7.85 (m, 2H, ArH), 7.80-7.77 (m, 2H, ArH), $7.39(\mathrm{~m}, 4 \mathrm{H}, \operatorname{ArH}), 4.39(\mathrm{t}, 4 \mathrm{H}, \mathrm{J}=6.9$ $\mathrm{Hz}, \mathrm{NCH}_{2}$ ), 1.84 (quin, $4 \mathrm{H}, \mathrm{J}=6.6 \mathrm{~Hz}$, $\left.\mathrm{NCH}_{2} \mathrm{CH}_{2}\right), \quad 1.31-1.17 \quad(\mathrm{~m}, \quad 28 \mathrm{H}$, $\left.\mathrm{CH}_{2}\left(\mathrm{CH}_{2}\right)_{7} \mathrm{CH}_{3}\right), 0.84(\mathrm{t}, 6 \mathrm{H}, J=6.7 \mathrm{~Hz}$, $\left.\mathrm{CH}_{2} \mathrm{CH}_{3}\right) .{ }^{13} \mathrm{C}$ NMR spectrum: $\delta 145.9(\mathrm{NCHN})$, $141.9,133.3,124.1,123.4,119.6,111.8$, $45.2\left(\mathrm{NCH}_{2}\right), 31.7,29.7,29.4,29.3,29.1$, $28.9,26.5,22.5,14.4 \quad\left(\mathrm{CH}_{2} \mathrm{CH}_{3}\right)$. LC-MS Calculated for $\left[\mathrm{Ag}\left(\mathrm{C}_{17} \mathrm{H}_{26} \mathrm{~N}_{2}\right)_{2}\right]^{+}, \mathrm{m} / \mathrm{z}$ : 623.3; Found, 623.4. Elemental analysis, Calculated for $\mathrm{C}_{34} \mathrm{H}_{52} \mathrm{AgN}_{5} \mathrm{O}_{3} ; \mathrm{C}, 59.47, \mathrm{H}, 7.63, \mathrm{~N}, 10.20$; Found; C, 59.37, H, 7.55, N, 10.16.

\section{In vitro CA inhibition assay Preparation of hemolysate and purification from red blood cells: Blood}

samples were taken from healthy human volunteers into anticoagulated tubes $(25 \mathrm{~mL})$. They were centrifuged at $5000 \mathrm{rpm}$ for $20 \mathrm{~min}$ at $4{ }^{\circ} \mathrm{C}$ and the plasma was removed. The erythrocytes in the tubes were washed with $0.9 \% \mathrm{NaCl}$ three times and then hemolyzed in cold water. The hemolysate was centrifuged at $15000 \mathrm{rpm}$ for $30 \mathrm{~min}$ at $4^{\circ} \mathrm{C}$ to remove ghosts and any intact cells and the $\mathrm{pH}$ of the hemolysate was adjusted to $\mathrm{pH} 8.5$ with solid Tris-base. The $25 \mathrm{~mL}$ hemolysate was applied to an affinity column containing L-tyrosinesulfonamide-Sepharose-4B (29) equilibrated with $25 \mathrm{mM}$ Tris- $\mathrm{HCl} / 0.1 \mathrm{M} \mathrm{Na}_{2} \mathrm{SO}_{4}(\mathrm{pH} 8.5)$. The affinity gel was washed with $50 \mathrm{~mL}$ of 25 $\mathrm{mM}$ Tris- $\mathrm{HCl} / 22 \mathrm{mM} \mathrm{Na}_{2} \mathrm{SO}_{4}(\mathrm{pH}$ 8.5). The human $\mathrm{CA}$ (hCA) isozymes were then eluted with $0.1 \mathrm{M} \mathrm{NaCl} / 25 \mathrm{mM} \mathrm{Na}_{2} \mathrm{HPO}_{4}(\mathrm{pH} \mathrm{6.3)}$ and $0.1 \mathrm{M} \mathrm{CH} \mathrm{CHONa}_{3} \mathrm{CO} \mathrm{M} \mathrm{NaClO}_{4}$ (pH 5.6), which recovered hCA I and II, respectively. Fractions ( $3 \mathrm{~mL}$ ) were collected and their absorbance was measured at $280 \mathrm{~nm}$ to see the protein density.

Esterase activity assay. As mentioned in the literature, the activity was assayed by following the change in absorbance at $348 \mathrm{~nm}$ of 4-nitrophenyl-acetate (NPA) to 4nitrophenylate ion over a period of $3 \mathrm{~min}$ at 25 ${ }^{\circ} \mathrm{C}$ using a spectrophotometer (Biotek, Winooski, VT) (30). The enzymatic reaction contained $1.4 \mathrm{~mL}$ of $0.05 \mathrm{M}$ Tris- $\mathrm{SO}_{4}$ buffer ( $\mathrm{pH} 7.4), 1 \mathrm{~mL}$ of $3 \mathrm{mM} 4$-nitrophenylacetate, $0.5 \mathrm{~mL} \mathrm{H}_{2} \mathrm{O}$ and $0.1 \mathrm{~mL}$ enzyme solution, in a total volume of $3.0 \mathrm{~mL}$. The inhibitory effects of the silver complexes (1-6) were examined. A reference measurement was obtained by preparing the same cuvette without enzyme solution. Different concentrations of the compounds were used.

In vitro inhibition studies. Different concentrations of the compounds were added to the enzyme for the inhibition. Activity percentage values of hCAI and $h$ CAII for different concentrations of each complex were determined by regression analysis using Microsoft Office 2000 Excel (Microsoft, Redmond, WA). CA enzyme activity without a silver complex solution was accepted to be $100 \%$ activity. Inhibitory effects of the compounds on enzyme activities were tested under in vitro conditions.

\section{RESULTS AND DISCUSSION}

\section{Synthesis and characterization of complexes}

In the scope of this study, we aimed the synthesis of novel silver(I)-benzimidazole complexes in order to investigate their carbonic anhydrase inhibitory properties. For this purpose, firstly, six $N$-alkylbenzimidazole derivatives were synthesized by the previously 
described method (28). The target complexes were prepared in good yields (64-94\%) by the reaction of $\mathrm{N}$-alkylbenzimidazole derivatives and silver nitrate in ethanol at $50{ }^{\circ} \mathrm{C}$ for 3 hours under ambient conditions as shown in Scheme 1. The structures of complexes were established by the combination of ${ }^{1} \mathrm{H} \mathrm{NMR},{ }^{13} \mathrm{C}$ NMR, mass spectrometry, FT-IR spectroscopic methods and elemental analyses as shown in "Supporting Information".

In the ${ }^{1} \mathrm{H}$ NMR spectra of complexes, the signals of $\mathrm{C}^{2}-\mathrm{H}$ imino hydrogens were observed in the range of 8.62-8.67 ppm for $\mathbf{1}$ and 3-6 and at lower field ( $\delta 8.77 \mathrm{ppm}$ ) for $\mathbf{2}$, by the presence of nitro group. For complex $\mathbf{3}$, allylic hydrogen was observed as doublet of doublet of triplets with three coupling constants. In the ${ }^{13} \mathrm{C}$ NMR spectra of complexes, the resonances of $\mathrm{C}^{2}$-imino carbons were observed in the range of $145.8-$ 146.6 ppm for $\mathbf{1}$ and 3-6 and at $150.2 \mathrm{ppm}$ for
2. All these signals for both ${ }^{1} \mathrm{H}$ and ${ }^{13} \mathrm{C} N M R$ are consistent with the literature (31). LC-MS spectra of complexes were recorded for further characterization, and the peaks observed at $371.0,463.0,425.1,483.2,513.3$, and 623.4 $\mathrm{m} / \mathrm{z}$ can be attributed to $\mathrm{Ag}$ (benzimidazole) $2^{+}$ part of complexes. In the FT-IR spectra of the complexes, the strong bands in the range of $1459-1475 \mathrm{~cm}^{-1}$ are attributable to $\mathrm{C}=\mathrm{N}$ bond which contain coordinated nitrogen to silver center (32). Based on spectroscopic data and elemental analyses, the cationic silver complexes (1-6) contain two benzimidazole molecules as shown in Scheme 1. Another point we must underline that, melting point of complexes 4-6 decreased to below $100^{\circ} \mathrm{C}$ as shown in Table 1. In 2004, Lee et al. showed that similar long chain containing imidazole complexes of silver(I) have liquid crystalline properties. Therefore, decreased melting points of the complexes are not surprising and consistent with literature (33).
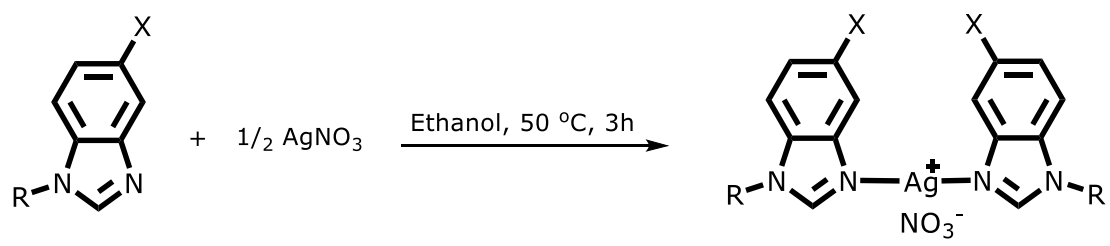

1-6

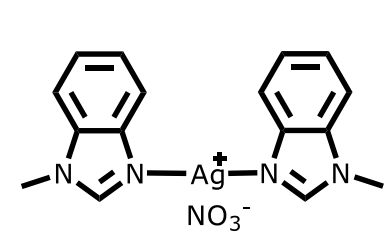

1

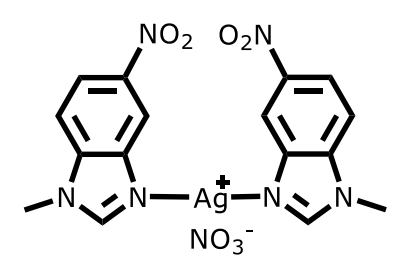

2

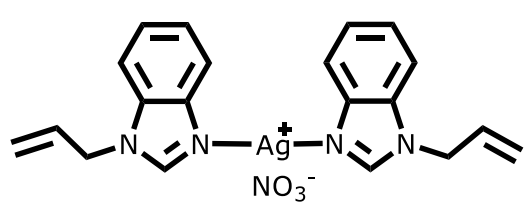

3

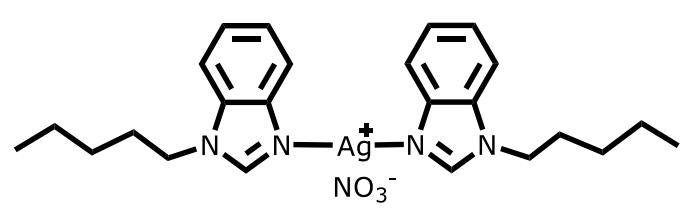

4

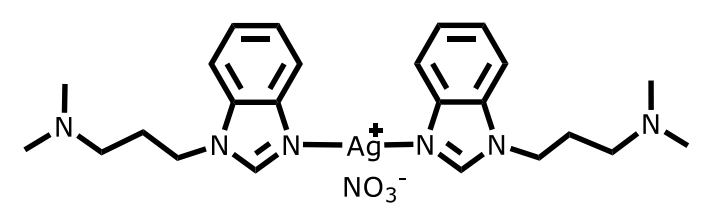

5

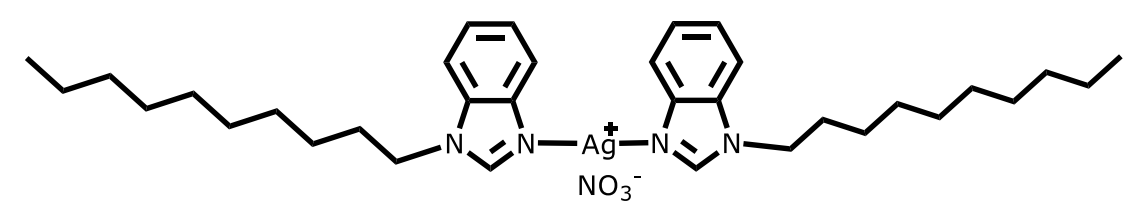

6

Scheme 1. Synthesis and structure of silver(I)-benzimidazole complexes (1-6). 
Table 1. Physical, spectral properties and $\mathrm{IC}_{50}$ values of complexes.

\begin{tabular}{|c|c|c|c|c|c|c|c|c|}
\hline \multicolumn{3}{|c|}{ Structure } & \multicolumn{4}{|c|}{ Physical and spectral data } & \multicolumn{2}{|c|}{ IC $_{50}$ values $(\mu \mathrm{M})$} \\
\hline Compound & $\mathrm{R}$ & $x$ & Yield (\%) & M.P. $\left({ }^{\circ} \mathrm{C}\right)$ & $\operatorname{NCHN}(\delta)$ & $\mathrm{NCHN}(\delta)$ & hCA I & hCA II \\
\hline 1 & $-\mathrm{CH}_{3}$ & $-\mathrm{H}$ & 94 & $203-204$ & 8.62 & 146.6 & 29.14 & 26.23 \\
\hline 2 & $-\mathrm{CH}_{3}$ & $-\mathrm{NO}_{2}$ & 90 & $281-283$ & 8.77 & 150.2 & 27.37 & 20.93 \\
\hline 3 & $-\mathrm{CH}_{2} \mathrm{CH}=\mathrm{CH}_{2}$ & $-\mathrm{H}$ & 64 & $128-130$ & 8.67 & 146.1 & 29.58 & 27.25 \\
\hline 4 & $-\mathrm{CH}_{2}\left(\mathrm{CH}_{2}\right)_{3} \mathrm{CH}_{3}$ & $-\mathrm{H}$ & 94 & $73-74$ & 8.67 & 146.0 & 29.55 & 24.72 \\
\hline 5 & $-\left(\mathrm{CH}_{2}\right)_{3} \mathrm{~N}\left(\mathrm{CH}_{3}\right)_{2}$ & $-\mathrm{H}$ & 66 & $87-88$ & 8.63 & 145.8 & 29.06 & 23.14 \\
\hline 6 & $-\mathrm{CH}_{2}\left(\mathrm{CH}_{2}\right)_{8} \mathrm{CH}_{3}$ & $-\mathrm{H}$ & 82 & $84-85$ & 8.66 & 145.9 & 28.18 & 22.59 \\
\hline \multicolumn{7}{|c|}{ Acetazolamide $^{(34)}$} & 4.6 & 3.9 \\
\hline
\end{tabular}




\section{CA Inhibition studies}

The inhibitory properties of all complexes were tested on the esterase activity of hCA I and II. IC $_{50}$ values were listed in Table $\mathbf{1}$ and all complexes inhibited the activity in micromolar level. Acetazolamide is a sulfonamide derived CA inhibitor and anti-glaucoma drug, and therefore we used as standard for comparison (34). As seen from Table 1, IC 50 values of complexes are higher than acetazolamide, and in the range of 27.37-29.58 $\mu \mathrm{M}$ for hCA I and 20.93-27.25 $\mu \mathrm{M}$ for hCA II. When we compare the activities of complexes, IC $_{50}$ values of all complexes are comparable with each other. Only nitro-substituted $\mathbf{2}$ performed slightly stronger inhibitory activity than others but it is difficult the reach any definite conclusion. Based on these results we suggest the length of chain on benzimidazole is not decisive on CA inhibitory activity. As we mentioned in the "Introduction" section, silver compounds have antimicrobial properties. Although the antimicrobial mechanisms of action are not completely known yet, some studies showed silver can kill bacteria by causing impairment or inhibition of some essential enzymes (3). Therefore, we suggest that the complexes, 16 perform the inhibitory activity by the interaction of silver with some residues.

Sulfonamides are the most used CA inhibitors and coumarin, amine, and phenol derivatives are other known inhibitors of CA (23). Although many inhibitors were developed for $C A$, there is still need for novel selective and non-toxic inhibitors. We think that although the activity of $\mathbf{1 - 6}$ is lower than acetazolamide, they may have an advantage that human body can tolerate silver in low concentrations without toxicity. Additionally, Supuran and co-workers reported that cationic compounds may be used as selective inhibitors of membrane-bound tumor-associated isoforms of CA (35-38) and complexes 1-6 deserve further investigation on the inhibition of the activity of membrane-bound isoforms of CA due to their ionic structure.

\section{CONCLUSION}

In conclusion, we reported the synthesis and characterization of six novel silver(I)- $N$ alkylbenzimidazole complexes. The complexes were fully characterized by appropriate spectroscopic methods and elemental analyses. Inhibitory properties of complexes were investigated on the esterase activity of hCA I and II. The results showed that all complexes inhibited the activity of hCA I and hCA II and it was observed that the length of the chain on benzimdazole does not affect the inhibitory activity for this type of complexes. In view of relative safety of silver compounds, we believe that the reported complexes deserve further research in CA inhibition and the treatment of glaucoma.

\section{CONFLICT OF INTEREST}

The authors report no conflicts of interest. The authors are alone responsible for the content and writing of paper.

\section{REFERENCES}

1. Klasen H. Historical review of the use of silver in the treatment of burns. I. Early uses. Burns. 2000;26;117-30.

2. Moyer CA, Brentano L, Gravens DL, Margraf HW, Monafo WW. Treatment of large human burns with 0.5 per cent silver nitrate solution. Arch Surg. 1965;90:812-67.

3. Fox CL. Silver sulfadiazine- A new topical therapy for Pseudomonas in Burns. Arch Surg. 1968;96:184-8.

4. Medici S, Peana M, Crisponi G, Nurchi VM, Lachowicz JI, Remelli M, Zoroddu MA. Silver coordination compounds: A new horizon in medicine. Coord Chem Rev. 2016;327328:349-59.

5. Allison SJ, Sadiq M, Baronou E, Cooper PA, Dunnill C, Georgopoulos NT, Latif A, Shepherd S, Shnyder SD, Stratford IJ, Wheelhouse RT, Willans CE, Phillips RM. Preclinical anti-cancer activity and multiple mechanisms of action of a cationic silver complex bearing $\mathrm{N}$-heterocyclic carbene ligands. Cancer Lett. 2017;403:98-107.

6. Teyssot $M L$, Jarrouse $A S$, Manin $M$, Chevry A, Roche S, Norre F, Beaudoin C, Morel L, Boyer D, Mahiou R, Gautier A. Metal-NHC complexes: a survey of anti-cancer properties. Dalton Trans. 2009;2009:6894-902.

7. Liu W, Gust R. Metal N-heterocyclic carbene complexes as potential antitumor metallodrug. Chem Soc Rev. 2013;42:755-73.

8. Rowan $R$, Tallon $T$, Sheahan $A M$, Curran R, McCann M, Kavanagh K, Devereux $M$, McKee $V$. 'Silver bullet' in antimicrobial chemotherapy: Synthesis, characterisation and biological screening of some new $\mathrm{Ag}(\mathrm{I})$ containing imidazole complexes. Polyhedron. $2006 ; 25: 1771-8$.

9. Ray $S$, Mohan $\mathrm{R}$, Singh JK, Samantaray MK, Shaikh MM, Panda D, Ghosh $P$. Anticancer and antimicrobial metallopharmaceutical agents based on palladium, gold, and silver $\mathrm{N}$-heterocyclic carbene complexes. J Am Chem Soc. 2007;129: 15042-53. 
10. Ainscough EW, Brodie AM, Freeman $\mathrm{GH}$, Plieger PG. Structural studies on tribenzylphosphane sulphide complexes of copper(I) and silver(I). Polyhedron. 2016;106:40-3.

11. Yadav G, Ganguly S. Structure activity relationship (SAR) study of benzimidazole scaffold for different biological activities: A mini-review. Eur J Med Chem. 2015;97:41943.

12. Song D, Ma S. Recent development of benzimidazole-containing antibacterial agents. ChemMedChem. 2016;11:646-59.

13. Gaba M, Mohan C. Development of drug-based imidazole and benzimidazole bioactive heterocycles: recent advances and future directions. Med Chem Res. 2016;25:173-210.

14. Rylands L, Welsh A, Maepa K, Stringer T, Taylor D, Chibale K, Smith GS. Structureactivity relationship studies of antiplasmodial cyclometallated ruthenium(II), rhodium(III), and iridium(III) complexes of 2phenylbenzimidazole. Eur J. Med Chem. 2019;161:11-21.

15. Gozelle $M$, Süloğlu AK, Selmaoğlu G, Ramazanoğlu N, Açık L, Gümüş $F$. Studies on the synthesis, characterization, cytotoxic activities and plasmid DNA binding of platinum(II) complexes having 2-substituted benzimidazole ligands. Polyhedron. 2019;161:298-308.

16. Su WY, Pan RK, Song JL, Li GB, Liu SG. Synthesis, crystal structures and cytotoxic activity of two zinc(II) complexes derived from benzimidazole derivatives. Polyhedron. 2019;161: 268-75.

17. Sarı Y, Akkoç S, Gök Y, Sifniotis V, Özdemi İ, Günal S, Kayser V. Benzimidazolium-based novel silver $\mathrm{N}$ heterocyclic carbene complexes: synthesis, characterization and in vitro antimicrobial activity. J Enzyme Inhib Med Chem. 2016;31:1527-30.

18. Touj N, Özdemir İ, Yaşar S, Hamdi N. An Efficient (NHC) copper(I)-catalyst for azide-alkyne cycloaddition reactions for the synthesis of 1,2,3-trisubstituted triazoles: Click chemistry. Inorg Chim Acta. 2017;467:21-32.

19. Kaloğlu N, Kaloğlu M, Tahir MN, Arıcı C, Bruneau C, Doucet $H$, Dixneuf $\mathrm{PH}$, Çetinkaya B, Özdemir İ. Synthesis of Nheterocyclic carbene-palladium-PEPPSI complexes and their catalytic activity in the direct $\mathrm{C}-\mathrm{H}$ bond activation. J Organomet Chem. 2018;867:404-12.

20. Şahin-Bölükbaşı $S$, Şahin N, Tahir MN, Arıcı C, Çevik E, Gürbüz N, Özdemir İ, Cummings BS. Novel $\mathrm{N}$-heterocyclic carbene silver(I) complexes: Synthesis, structural characterisation, and anticancer activity. Inorg Chim Acta. 2019;486:711-8.

21. Aktaş A, Celepci D, Kaya R, Taslimi P, Gök Y, Aygün M, Gülçin İ. Novel morpholine liganded Pd-based N-heterocyclic carbene complexes: Synthesis, characterization, crystal structure, antidiabetic and anticholinergic properties. Polyhedron. 2019;159:345-54.

22. Supuran CT, Scozzafava A, Casini A. Carbonic anhydrase inhibitors. Med Res Rev. 2003;23:146-89.

23. Supuran CT. Carbonic anhydrase inhibitors. Bioorg Med Chem Lett. 2010;20:3467-74.

24. Kupriyanova E, Pronind N, Los D. Carbonic anhydrase- a universal enzyme of carbon-based life. Photosynthetica. 2017;55:3-19.

25. Aggarwal M, Kondeti B, McKenna R. Anticonvulsant/antiepileptic carbonic anhydrase inhibitors: a patent review. Expert Opin Ther Pat. 2013;23:717-24.

26. Scozzafava A, Supuran CT, Carta F. Antiobesity carbonic anhydrase inhibitors: a literature and patent review. Expert Opin Ther Pat. 2013;23:725-35.

27. Monti BM, Supuran CT, De Simone G. Anticancer carbonic anhydrase inhibitors: a patent review (2008-2013). Expert Opin Ther Pat. $2013 ; 23: 737-49$.

28. Özdemir İ, Şahin N, Gök Y, Demir S, Çetinkaya B. In situ generated 1alkylbenzimidazole palladium catalyst for the Suzuki coupling of aryl chlorides. J Mol Catal A-Chem. 2005;234:181-5.

29. Arslan O, Nalbantoğlu B, Demir N, Özdemir $H$, Küfrevioğlu Öİ. A new method for the purification of carbonic anhydrase isozymes by affinity chromatography. Turk J Med Sci. 1996;26:167-70.

30. Verpoorte JA, Mehta S, Edsall JT. Esterase activities of human carbonic anhydrases B and C. J Biol Chem. $1967 ; 242: 4221-9$. 
31. Karlık Ö, Balcıoğlu S, Karataş MO, Ateş B, Alıcı B, Özdemir N. Synthesis, structural characterization and cytotoxicity studies of Tshaped silver(I) complexes derived from 1benzyl-3H-benzimidazolium toluenesulfonates. Polyhedron. 2018;142:6370.

32. Wu H, Zhang $Y$, Chen $C$, Zhang J, Bai $Y$, Shi $F$, Wang $X$. DNA binding studies and antioxidant activities of two-, three- and fourcoordinate silver(I) complexes containing bis(2-benzimidazolyl)aniline derivatives. New J Chem. 2014;38:3688-98.

33. Lee CK, Hsu KM, Tsai CH, Lai CK, Lin IJB. Liquid crystals of silver complexes derived from simple 1-alkylimidazoles. Dalton Trans. 2004;2004:1120-6.

34. Büyükkıdan $N$, Bülbül $M$, Kasımoğulları $R$, Büyükkıdan B. Synthesis and characterization of metal complexes of heterocyclic sulphonamide as carbonic anhydrase inhibitors. J Enzyem Inhib Med Chem. 2013;28:311-5.
35. Scozzafava A, Briganti F, Ilies MA, Supuran CT. Carbonic anhydrase inhibitors: Synthesis of membrane-impermeant low molecular weight sulfonamides possessing in vivo selectivity for the membrane-bound versus cytosolic isozymes. J Med Chem. 2000;43:292-300.

36. Casey JR, Morgan PE, Vullo D, Scozzafava A, Mastrolorenzo A, Supuran CT. Carbonic anhydrase inhibitors. Design of selective, membrane-impermeant inhibitors targeting the human tumor-associated isozyme IX. J Med Chem. 2004;49:2337-47.

37. Güzel Ö, Maresca A, Scozzafava A, Salman A, Balaban AT, Supuran CT. Discovery of low nanomolar and subnanomolar inhibitors of the Mycobacterial $\beta$-carbonic anhydrases Rv1284 Rv3273. J Med Chem. 2009;52:40637.

38. Akocak S, Ilies MA. Targeting carbonic anhydrases. London:Future Science;2014:3551. 